\title{
ISOLATION OF MANGANESE-SUPEROXIDE DISMUTASE FROM SACCHAROMYCES CEREVISIAE
}

\author{
by \\ CHARLES DITLOW" and JACK T. JOHANSEN ${ }^{2)}$ \\ Department of Chemistry, Carlsberg Laboratory, \\ Gamle Carlsberg Vej 10, DK-2500 Copenhagen Valby \\ 1) Present address: Biophysics Research Laboratory, Department of Biochemistry Harvard Medical School \\ and Brigham and Women's Hospital, Boston, MA 02115 \\ 2) Carlsberg Biotechnology Ltd, A/S \\ Tagensvej 16, DK-2200 Copenhagen N
}

Keywords: Manganese superoxide dismutase, S. cerevisiae

The manganese containing mitochondrial superoxide dismutase from Saccharomyces cerevisiae, baker's yeast has been purified to homogeneity by a new large scale procedure. The purified enzyme exhibits a molecular weight of 89,000 and is composed of 4 subunits of equal size. The native tetramer readily dissociates into subunits in $1 \%$ SDS at $100^{\circ} \mathrm{C}$ in the absence of 2-mercaptoethanol. The enzyme contains 4 atoms of manganese per tetramer. The ultraviolet and visible spectra of the yeast enzyme closely resemble the spectra of manganese superoxide dismutases of other organisms. The purified veast enzyme is free of carbohydrates.

\section{INTRODUCTION}

Superoxide dismutase (SOD) (E.C. 1.15.1.1) catalyzes the dismutation of superoxide radicals, producing hydrogen peroxide and molecular oxygen $(9,15)$. Three distinct types of SOD, all of them metalloenzymes, have been identified. Copper-zinc SOD, from the cytoplasm of eukaryotes, is a dimer with a subunit molecular weight of 16,000. Manganese SOD, found in mitochondria and prokaryotes, is either a dimer or tetramer with a subunit molecular weight of about 20,000 . Iron SOD, found only in prokaryotes, is a dimer with a subunit molecular weight of 20,000. Amino terminal sequence analyses suggest that the manganese and iron forms of SOD have evolved from a common ancester

Abbreviations: DTNB $=2,2^{\prime}$-dinitro-5,5'-dithiodibanzoic acid; SDS $=$ sodium dodecylsulfate; SOD $=$ superoxide dismutase; Tris = 2-amino-2-hydroxymethyl-1,3-propanediol. 
while copper-zinc SOD appears to have evolved from an independent source (14).

Both the cytoplasmic copper-zinc SOD (12) and the mitochondrial manganese SOD (24) have been isolated from Saccharomyces cerevisiae. Recently, the complete amino acid sequence of copper-zinc SOD from bakers' yeast has been determined at this laboratory (16). Preliminary to the planned sequence analysis of manganese SOD from Saccharomyces cerevisiae a new purification procedure for this enzyme, on a moderately large scale, has been developed. This procedure and a characterization of the purified product are presented below.

\section{MATERIALS AND METHODS \\ 2.1. Materials}

Pressed cake bakers' yeast was purchased from De Danske Spritfabrikker A/S, Copenhagen, Denmark. DE-52 cellulose was obtained from Whatman Biochemicals, Maidenstone, England. DEAE-Sepharose CL-6B, Sephadex G-25, and 4/30\% gradient polyacrylamide gels were from Pharmacia Fine Chemicals, Uppsala, Sweden. Sodium dodecylsulfate (SDS), specially purified for biochemical work, was obtained from BDH Chemicals, Ltd., Poole, England. Nitro blue tetrazolium was purchased from the Sigma Chemical Company, St. Louis, Missouri, USA. Sodium dimethylarsinate, 1,2,3-trihydroxybenzene, and 2,2'-dinitro-5,5'-dithiodibenzoic acid (DTNB) were from Merck Chemical Company, Darmstadt, Germany. All other chemicals were analytical grade.

\subsection{Methods}

SOD was assayed on the basis of its ability to inhibit the autoxidation of 1,2,3-trihydroxybenzene in Tris-dimethylarsinate buffer at pH 8.2 (21). Manganese SOD activity was distinguished from the activity of copper-zinc SOD by the addition of $1 \mathrm{~mm}-\mathrm{KCN}$ to the assay mixture, which inhibits the copper-zinc SOD activity but not that of the manganese enzyme (31). Assays in the presence of $\mathrm{KCN}$ were corrected for the effects of cyanide upon the sensitivity of the assay (21). All assays were performed in a thermostated cuvette holder at $420 \mathrm{~nm}$ with a Cary 219 recording spectrophotometer at $\mathbf{2 5 . 0}$ $\pm 0.1^{\circ} \mathrm{C}$. SOD bands in polyacrylamide gels were visualized by the nitro blue tetrazolium photoreduction assay (1).

Protein concentrations were determined by the method of Lowry et al. (20) using bovine serum albumin as a protein standard, except in the case of the purified manganese SOD, where protein concentrations were determined by amino acid analysis. Protein samples for amino acid analysis were hydrolyzed in vacuo for 24 , 48,72 , and 96 hours at $110^{\circ} \mathrm{C}$ in constant boiling $5.7 \mathrm{~m}-\mathrm{HCl}$. Hydrolysates were analysed on a Durrum 500 automatic amino acid analyser. Tryptophan was estimated by the spectrophotometric method of EDELHOCH (6). Half cystine was determined by amino acid analysis after performic acid oxidation of the enzyme (17). Free sulfhydryls were detected by their reaction with DTNB in either $0.1 \mathrm{~m}$-TrisCl, 1 mм-EDTA, pH 7.9 or 0.1 м-Tris-Cl, 5 мurea, 1 mм-EDTA, pH $7.9(7,26)$.

Disc polyacrylamide gel electrophoresis was performed as described by DAvis (4) with the omission of the sample and stacking gels. Molecular weight determination by gradient polyacrylamide gel electrophoresis was carried out in accordance with the instructions given by Pharmacia Fine Chemicals. The molecular weight of the manganese SOD subunit was determined by electrophoresis in $10 \%$ polyacrylamide gels in the presence of $1 \%$ SDS as described by Fairbanks et al. (8). Protein bands were stained with Coomassie brilliant blue (8).

Antisera were produced by subcutaneous injection of $10 \mathrm{mg}$ manganese SOD emulsified with Freund's complete adjuvant at four discrete dorsal locations on each rabbit, followed by an intravenous booster of $4 \mathrm{mg}$ manganese SOD one month later. One week after the booster injections, serum was collected from each rabbit by ear bleeding. The immunoglobulin fraction of the pooled sera was partially purified by $\left(\mathrm{NH}_{4}\right)_{2} \mathrm{SO}_{4}$ precipitation as described by $\mathrm{H}_{\text {ARBOE }}$ and INGILD (13). Crossed immunoelectrophoresis in $1 \%$ agarose gels were performed according to the method of KRøLL (19).

Molecular weight determination by sedimentation equilibrium was performed in a BeckmanSpinco Model E ultracentrifuge as described by Chervenka (3). Metal free buffers were prepared by extraction with $0.01 \%$ dithizone in $\mathrm{CCl}_{4}$ 
(29). Metals were determined by atomic absorption with a Perkin-Elmer Model 603 atomic absorption spectrometer. Reducing sugars were estimated by the $\mathrm{H}_{2} \mathrm{SO}_{4}$, phenol method of Dusors et al (5). Amino sugars were determined chromatographically on the short column of a Beckman-Spinco Model $120 \mathrm{C}$ amino acid analyser after short term hydrolysis of the protein (23).

\section{RESULTS}

\subsection{Enzyme purification}

Pressed cake bakers' yeast, $10 \mathrm{~kg}$, was suspended in 10 liter $0.1 \mathrm{~m}-\mathrm{K}_{2} \mathrm{HPO}_{4}$ at $4{ }^{\circ} \mathrm{C}$ and the $\mathrm{pH}$ of the suspension adjusted to 8 with concentrated $\mathrm{NH}_{4} \mathrm{OH}$. The suspension was homogenized three times with a Gaulin type $15 \mathrm{M}$ 8TA laboratory homogenizer at 450 $\mathrm{kg} \cdot \mathrm{cm}^{-1}$. The temperature of the homogenate was maintained below $30^{\circ} \mathrm{C}$ by means of a Hetofrig cooling unit equipped with a stainless steel heat exchanger coil. Steam was passed through the homogenate until a temperature of $70^{\circ} \mathrm{C}$ was reached (3-4 min). This temperature was maintained for $2 \mathrm{~min}$ while the homogenate

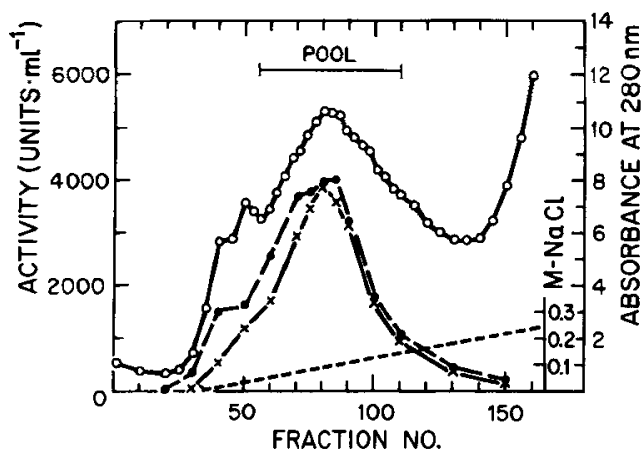

Figure 1. Chromatography on DE-52 cellulose.

The desalted ultrafilter concentrate was applied to a $10 \times 12 \mathrm{~cm}$ DE-52 column equilibrated with 10 mM-Tris-Cl, $\mathrm{pH} 7.9$, at a flow rate of $420 \mathrm{ml} \cdot \mathrm{hr}^{-1}$. The column was washed with equilibration buffer and the bound $\mathrm{Mn}-\mathrm{SOD}$ eluted with a $\mathrm{NaCl}$ gradient, $25 \mathrm{ml}$ fractions were collected. The SOD active fractions were pooled as indicated. $(-x-x-x-)$ SOD activity in the presence of $1 \mathrm{~mm}-\mathrm{KCN}$. $(-0-1)$ SOD activity in the absence of KCN. $(-\mathrm{O}-\mathrm{O}-\mathrm{O}-)$ Adsorbance at $280 \mathrm{~nm}$. (---) $\mathrm{NaCl}$ concentration.

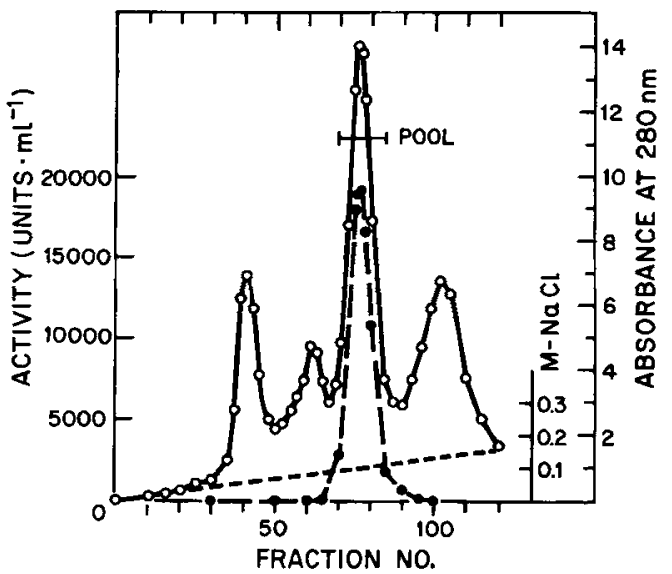

Figure 2. Chromatography on DEAE-Sepharose CL-6B.

The desalted enzyme solution was applied to a $5 \times 40 \mathrm{~cm}$ DEAE-Sepharose CL-6B column equili-

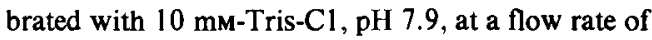
$150 \mathrm{ml} \cdot \mathrm{hr}^{-1}$. The column was washed with equilibration buffer and the bound Mn-SOD eluted with a $\mathrm{NaCl}$ gradient, $20 \mathrm{ml}$ fractions were collected. The SOD active fractions were pooled as indicated. (- - -) SOD activity in the absence of $\mathrm{KCN}$. (-O-O-O-) Absorbance at $280 \mathrm{~nm}$. (---) $\mathrm{NaCl}$ concentration.

was stirred thoroughly. After the addition of 10 liter crushed ice, reducing the temperature to about $40^{\circ} \mathrm{C}$, the homogenate was centrifuged at $4500 \times \mathrm{g}$ for $45 \mathrm{~min}$. The turbid, yellow-brown supernatant was desalted by repetitive dilution and reconcentration in an ultrafilter. The first dilution was made with deionized water and the subsequent dilutions with $10 \mathrm{~mm}-\mathrm{Tris}-\mathrm{Cl}, \mathbf{p H}$ 7.9. The desalting process was continued until the ultrafilter permeate exhibited a conductivity of less than $0.5 \mathrm{mS}$. The enzyme solution was then concentrated to a minimum volume. The turbid, cream coloured concentrate was applied to a $10 \times 12 \mathrm{~cm}$ DE-52 cellulose column equilibrated in $10 \mathrm{~mm}-\mathrm{Tris}-\mathrm{Cl}, \mathrm{pH}$ 7.9. A large amount of unbound protein, containing no SOD activity, was washed from the column with equilibration buffer. The bound manganese SOD was eluted with a linear gradient of $\mathrm{NaCl}$, Figure 1. The clear, yellow-brown SOD pool was desalted by repeated dilution with $10 \mathrm{~mm}$ Tris-C1, $\mathrm{pH} 7.9$, and concentrated by ultrafiltra- 
tion. The desalting process was continued until the permeate exhibited a conductivity of less than $0.6 \mathrm{mS}$. The protein solution was then applied to a $5 \times 40 \mathrm{~cm}$ DEAE-Sepharose CL-6B column equilibrated in $10 \mathrm{~mm}$-Tris- $\mathrm{Cl}, \mathrm{pH}$ 7.9. The column was washed with $200 \mathrm{ml}$ buffer and the bound manganese SOD eluted with a linear gradient of $\mathrm{NaCl}$, Figure 2. The SOD active fractions were pooled and lyophilized.

The lyophilized material was redissolved in a minimum volume glass distilled water and residual undissolved material removed by centrifugation at $40,000 \times \mathrm{g}$ for $60 \mathrm{~min}$ at $4^{\circ} \mathrm{C}$. The reddish-brown supernatant was dialyzed against 400 volumes metal-free 10 mM-Tris- $\mathrm{Cl}$, pH 7.9 for 16 hours at $4^{\circ} \mathrm{C}$. Dialysis was then continued for an additional 100 hours at $4^{\circ} \mathrm{C}$ against at least 6 changes of 400 volumes glass distilled water. During dialysis numerous large, branched, reddish-purple manganese SOD crystals were formed, as well as, during the final 20 hours, a small amount of white non-crystalline precipitate. The crystals were isolated by centrifugation, washed once with ice cold distilled water and redissolved in a small volume metal free $0.1 \mathrm{~m}$-Tris- $\mathrm{Cl}, \mathrm{pH}$ 7.9. The insoluble precipitate was removed by centrifugation at
$40,000 \times \mathrm{g}$ for $30 \mathrm{~min}$ at $4{ }^{\circ} \mathrm{C}$. The burgundy coloured supernatant, containing the purified enzyme, was stored frozen at $-20^{\circ} \mathrm{C}$. This purification procedure is summarized in Table I.

\subsection{Homogeneity}

The purified manganese SOD exhibited a specific activity of 3,600 units per mg protein. The value was not changed by either the recrystallization of the enzyme or by the addition of $1 \mathrm{~mm}-\mathrm{KCN}$ to the assay mixture. Crossed immunoelectrophoresis of a yeast homogenate against antiserum prepared using the purified enzyme as an antigen, showed that the purified material contained only a single yeast protein. The homogeneity of the product was further demonstrated by the single protein bands obtained after gradient and SDS polyacrylamide gel electrophoresis.

Yeast manganese SOD was resolved into two protein bands by disc polyacrylamide gel electrophoresis at $\mathrm{pH} 8.3$. Both of the bands exhibited SOD activity in the presence of KCN. Neither the relative mobilities nor the intensities of the two bands were affected by the recrystallization of the enzyme.

\section{Table I}

Purification of manganese superoxide dismutase from bakers' yeast.

\begin{tabular}{lcccccc}
\hline $\begin{array}{l}\text { Purification } \\
\text { step }\end{array}$ & $\begin{array}{c}\text { Volume } \\
\mathrm{ml}\end{array}$ & $\begin{array}{c}\text { Protein } \\
\text { concentrate } \\
\mathrm{mg} \cdot \mathrm{ml}^{-1}\end{array}$ & $\begin{array}{c}\text { Total } \\
\text { protein } \\
\mathrm{mg}\end{array}$ & $\begin{array}{c}\text { Total } \\
\text { activity } \\
\text { units } \cdot 10^{-6}\end{array}$ & $\begin{array}{c}\text { Specific } \\
\text { activity } \\
\text { units } \mathrm{mg}^{-1}\end{array}$ & $\begin{array}{c}\text { Yield } \\
\%\end{array}$ \\
\hline $\begin{array}{l}\text { Ultrafilter } \\
\text { concentrate }\end{array}$ & 8000 & 5.8 & 47,000 & $5.0^{\mathrm{a}}$ & 100 & 100 \\
$\begin{array}{l}\text { DE-52 pool } \\
\begin{array}{l}\text { DEAE-Sepharose } \\
\text { CL-6B pool }\end{array}\end{array}$ & 1400 & 11.2 & 16,000 & $4.5^{\mathrm{a}, \mathrm{b}}$ & 290 & 90 \\
$\begin{array}{l}\text { Crystalization } \\
\text { concentrate }\end{array}$ & 270 & 8.2 & 2,200 & $3.2^{\mathrm{b}}$ & 1450 & 65 \\
$\begin{array}{l}\text { Redissolved } \\
\text { crystals }\end{array}$ & 15.5 & 130 & 2,000 & $3.2^{\mathrm{b}}$ & 1600 & 65 \\
\hline
\end{tabular}

SOD activities were determined in $50 \mathrm{~mm}$-Tris-cacodylate buffer $\mathrm{pH} 8.2$, containing $1 \mathrm{~mm}$-diethylenetriamine pentaacetic acid and $0.2 \mathrm{mM}-1,2,3$-trihydroxybenzene a) in the presence of $1 \mathrm{mM}-\mathrm{KCN}$, and $b$ ) in the absence of $\mathrm{KCN}(19)$. 


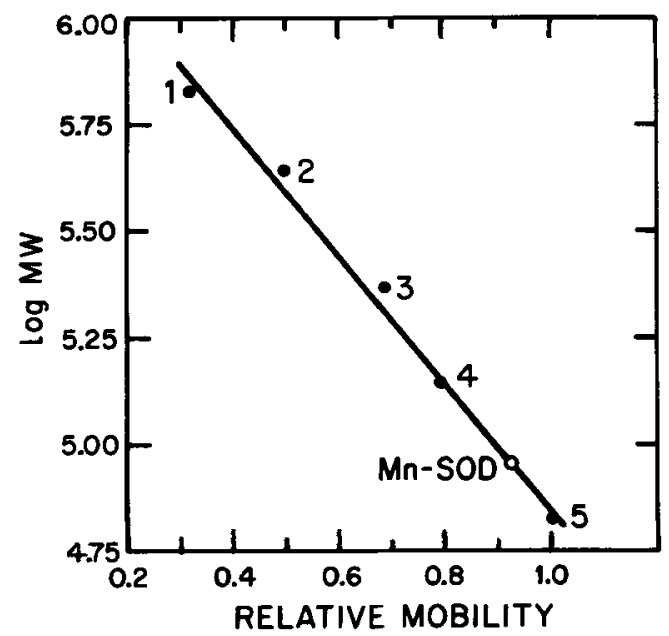

Figure 3. Determination of the molecular weight of yeast manganese SOD by electrophoresis in $4 / 30 \%$ gradient polyacrylamide gels.

Electrophoresis was carried out at pH 8.4 at $125 \mathrm{~V}$ for 16 hours at $10^{\circ} \mathrm{C}$. Molecular weight standards: 1. thryroglobulin $(669,000), 2$ ferritin $(440,000)$, 3. catalase $(232,000)$ 4. lactate dehydrogenase $(140,000)$, and 5 . bovine serum albumin $(67,000)$.

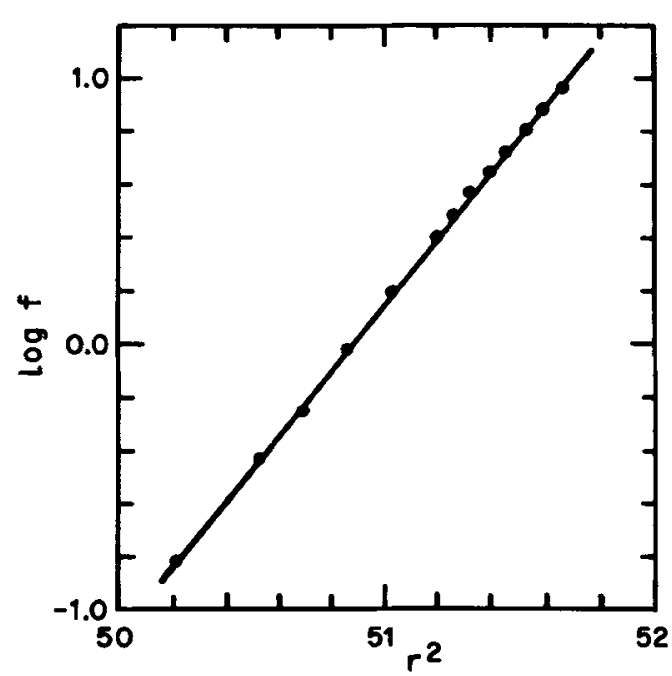

Figure 4. Sedimentation equilibrium of yeast manganese SOD.

The enzyme, $2 \mathrm{mg} \cdot \mathrm{ml}^{-1}$ in $10 \mathrm{~mm}-$ Tris- $\mathrm{Cl}, \mathrm{pH}$ 7.8 , was brought to equilibrium at a rotor speed of $15,220 \mathrm{rpm}$. A molecular weight of 89,000 was calculated from the slope of the logarithm of fringe displacement versus radial distance squared plot.

\subsection{Molecular weight}

Electrophoresis of yeast manganese SOD in $4 / 30 \%$ gradient polyacrylamide gels at $\mathrm{pH} 8.4$ gave a single sharp protein band whose relative mobility corresponded to a molecular weight of 92,000 , Figure 3. When the enzyme was brought to sedimentation equilibrium in $10 \mathrm{~mm}$ Tris-Cl, $\mathrm{pH} 7.8$ at $25^{\circ} \mathrm{C}$, a linear plot of the logarithm of the fringe displacement as a function of the square of the radial distance was obtained, Figure 4. A molecular weight of 89,000 was calculated from the slope of this plot, using an estimated value for the partial specific volume of 0.730 .

\subsection{Subunit structure}

Yeast manganese SOD dissociated into subunits when treated with $1 \% \operatorname{SDS}$ at $100^{\circ} \mathrm{C}$ for $2 \mathrm{~min}$ with or without the addition of 2 mercaptoethanol. The dissociated enzyme migrated as a single band in SDS polyacrylamide gels, whose mobility corresponded to a subunit molecular weight of 22,000 , Figure 5 . Thus, it

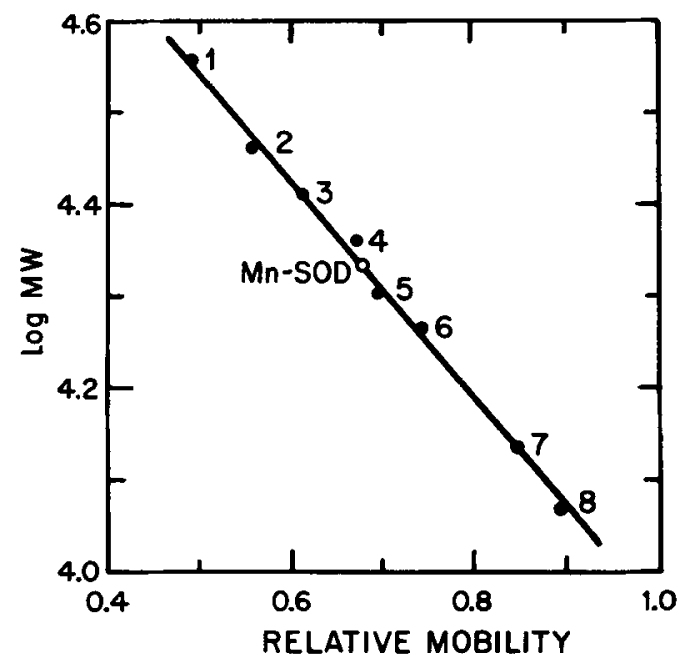

Figure 5. Subunit molecular weight of yeast manganese SOD determined by SDS polyacrylamide gel electrophoresis.

Molecular weight standards: 1. lactate dehydrogenase $(36,000), 2$. human carbonic anhydrase $(28,900)$, 3. chymotrypsinogen $(25,700), 4$. papain $(23,000), 5$. soyabean trypsin inhibitor $(20,100), 6$. $\beta$ lactoglobulin $(18,400), 7$. ribonuclease $(13,700)$, and 8. cytochrome c $(11,700)$. 
Table II

Amino acid composition of manganese superoxide dismutase from Saccharomyces cerevisiae.

\begin{tabular}{|c|c|c|c|c|}
\hline \multirow[t]{3}{*}{$\begin{array}{l}\text { Amino } \\
\text { acid }\end{array}$} & \multicolumn{2}{|c|}{$\begin{array}{c}\text { Saccharomyces } \\
\text { cerevisiae }\end{array}$} & \multirow{3}{*}{$\begin{array}{c}\begin{array}{c}\text { E. coli } \\
(28) \\
\text { residues }\end{array} \\
\text { subunit }\end{array}$} & \multirow{3}{*}{$\begin{array}{c}\begin{array}{c}\text { B. stearo- } \\
\text { thermophilus (2) } \\
\text { residues }\end{array} \\
\text { subunit }\end{array}$} \\
\hline & moles $^{a}$ & residues & & \\
\hline & mol subunit & subunit & & \\
\hline Asx & 24.0 & 24 & 24 & 25 \\
\hline Thr & 10.7 & 11 & 9 & 11 \\
\hline $\operatorname{Ser}^{b}$ & 8.1 & 8 & 11 & 11 \\
\hline Glx & 23.7 & 24 & 19 & 21 \\
\hline Pro & 9.0 & 9 & 9 & 13 \\
\hline Gly & 17.4 & 17 & 13 & 15 \\
\hline Ala & 18.4 & 18 & 26 & 20 \\
\hline Cys $^{c}$ & 1.0 & 1 & 0 & 0 \\
\hline $\mathrm{Val}^{\mathrm{d}}$ & 11.1 & 11 & 10 & 8 \\
\hline Met & 1.1 & 1 & 2 & 2 \\
\hline $\mathrm{Ile}^{\mathrm{d}}$ & 9.9 & 10 & 6 & 9 \\
\hline Leu & 19.0 & 19 & 21 & 19 \\
\hline Tyr & 7.7 & 8 & 7 & 8 \\
\hline Phe & 9.9 & 10 & 11 & 8 \\
\hline His & 5.7 & 6 & 8 & 9 \\
\hline Lys & 15.0 & 15 & 17 & 12 \\
\hline $\mathrm{Arg}$ & 2.8 & 3 & 6 & 6 \\
\hline Trpe & 6.0 & 6 & 6 & 6 \\
\hline Total & & 201 & 205 & 203 \\
\hline
\end{tabular}

a) Calculated on the basis of a molecular weight of 89,000 from duplicate samples hydrolysed for $24,48,72$, and 96 hours.

b) Extrapolated to zero hours hydrolysis time.

c) As cysteic acid after performic acid oxidation of the protein.

d) Value after 96 hours hydrolysis.

e) Determined spectrophotometrically (6).

appears that manganese SOD from bakers' yeast is composed of four subunits of identical molecular weight which are joined together by non-covalent forces.

\subsection{Amino acid analysis}

The amino acid composition of the purified yeast enzyme is listed in Table II, together with the compositions of two other types of manganese SOD whose primary structures are known. Although the two bacterial forms are dimers while the yeast enzyme is a tetramer, the three compositions are clearly similar.

Treatment of the native or urea denatured yeast SOD with the sulfhydryl reagent DTNB produced 0.9 moles thionitrobenzoic acid per mol subunit after 60 min reaction time. Thus, yeast manganese SOD appears to contain a single free sulfhydryl group per subunit and no disulfide bonds.

\subsection{Metal analysis}

Metal contaminants not involved in catalysis were removed from the purified enzyme by gel filtration on acid washed Sephadex G-25 in metal-free buffer. The specific activity of the enzyme was not affected by this treatment. Atomic absorption analysis of the gel filtered material indicated that yeast manganese SOD contains 1 atom of manganese per subunit, Table III. Only insignificant amounts of the metals found in other forms of SOD were found. 


\section{Table III}

Metal content of yeast manganese superoxide dismutase. Values were calculated on the basis of a molecular weight of 89,000 .

\begin{tabular}{cc}
\hline & \multicolumn{1}{c}{ moles } \\
\cline { 2 - 2 } Metal & mol subunit \\
\hline $\mathrm{Mn}$ & 1.06 \\
$\mathrm{Fe}$ & 0.10 \\
$\mathrm{Zn}$ & 0.04 \\
$\mathrm{Cu}$ & 0.00 \\
\hline
\end{tabular}

\subsection{Spectral porperties}

The ultraviolet and visual absorption spectra of yeast manganese SOD are shown in Figure 6. In the ultraviolet region the enzyme exhibits a maximum at $282 \mathrm{~nm}$ with shoulders at 278 and $290 \mathrm{~nm}$. The molar extinction coefficient at 282 $\mathrm{nm}$ is $1.88 \times 10^{5} \mathrm{M}^{-1} \cdot \mathrm{cm}^{-1}$, calculated on the basis on amino acid analysis and a molecular

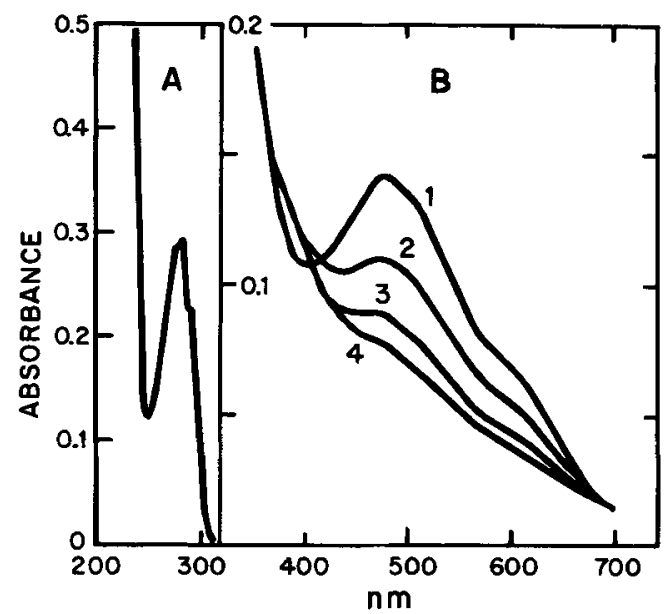

Figure 6. Adsorption spectra of yeast manganese SOD.

Spectra were recorded with a Cary 219 spectrophotometer after gel filtration of the enzyme on acid washed Sephadex G-25 in metal free $10 \mathrm{~mm}$-Tris-Cl, $\mathrm{pH}$ 7.8. A) Absorption in the ultraviolet region, $0.137 \mathrm{mg} \mathrm{Mn}$-SOD $\cdot \mathrm{ml}^{-1}$. B) Absorption in the visible region, $13.8 \mathrm{mg} \mathrm{Mn}-\mathrm{SOD} \cdot \mathrm{ml}^{-1}$. 1) The resting enzyme. The same solution, following the addition of $3.3 \mathrm{~mm}$-ascorbate, after 2) $15 \mathrm{~min}, 3) 30 \mathrm{~min}$, and 4) $45 \mathrm{~min}$. No further change was seen after $45 \mathrm{~min}$. weight of 89,000 . In the visible region the absorption spectrum of the yeast enzyme, with a maximum at $478 \mathrm{~nm}$, shoulders at 510 and 590 $\mathrm{nm}$, and a minimum at $400 \mathrm{~nm}$, closely resembles the visible absorption spectra of the manganese SOD's isolated from several other organisms $(18,22,25,31)$. Reduction of the yeast manganese SOD with ascorbate resulted in a significant decrease in its absorbance at visible wavelengths, Figure 6 . This is consistent with the proposal that the manganese in manganese SOD is trivalent in the resting enzyme (30).

\subsection{Carbohydrates}

Only insignificant amounts of reducing sugars, less than 2 hexose molecules per native tetramer were found in the purified enzyme. Non-reducing, amino sugars could not be detected. Thus, yeast manganese SOD does not appear to contain any intrinsic carbohydrates.

\section{DISCUSSION}

Superoxide dismutases are believed to function as scavengers of the potentially cytotoxic superoxide radicals formed during aerobic metabolism $(10,11)$. Amino acid sequence analyses of superoxide dismutases from a number of organisms have underscored the biological importance of these enzymes by indicating the existence of two evolutionarily distinct classes of $\operatorname{SOD}(14,27,28)$. The primary structures of the amino terminal regions of three mitochondrial manganese superoxide dismutases are known (14). However, to date, no complete sequence analysis of a mitochondrial SOD has been reported. The purification procedure presented above was developed in order to produce sufficient material for the determination of the complete amino acid sequence of yeast manganese SOD.

A purification procedure for small amounts of manganese SOD from bakers' yeast was published earlier by RavindRaNaTH and FrIDOVICH (24). Compared with the present paper, these authors reported a somewhat larger molecular weight and a significantly different visual absorption spectrum for the enzyme. Further, RAVINDRANATH and FrIDOVICH found that yeast manganese SOD contains 2 half cystine residues 
per subunit, one of which reacted as a free sulfhydryl, and that the enzyme did not dissociate fully in $1 \%$ SDS at $100^{\circ} \mathrm{C}$ without the addition of 2-mercaptoethanol. On this basis is was concluded that the native tetramer is composed of a pair of disulfide bonded dimers (24). In contrast, we have found that yeast manganese SOD contains a single half cystine per subunit, present as a free sulfhydryl, and that the enzyme readily dissociates into monomers when treated with $1 \% \mathrm{SDS}$ at $100^{\circ} \mathrm{C}$ in the absence of reducing agents. Thus, we find that the native tetramer is associated by non-covalent forces only. Apart from these differences, the products of the two purification procedures appear to be identical.

\section{ACKNOWLEDGEMENTS}

The authors wish to thank Professor MaRTin OTTESEN for his support and discussions regarding this work. We are also grateful to Professor J. V. SpärCK of Statens Seruminstitut, Copenhagen, for the preparation of SOD antisera, to Dr. Torben Graves Petersen for assistance with the ultracentrifuge and to Dr. JoAN Dunbar for helpful suggestions. One of us, C.D., wishes to thank the board of the Carlsberg Laboratory for financial support. The excellent technical assistance of Mr. Thorkild BeEnfeldt, Ms. Bodil Corneliussen, and Ms. Edith Fubistrup is also gratefully acknowledged.

\section{REFERENCES}

1. Beauchamp, C. \& I. Fridovich: Superoxide dismutase: Improved assays and an assay applicable to acrylamide gels. Anal. Biochem. 44, 276-287 (1971)

2. Brock, C. J. \& J. E. W alker: Superoxide dismutase from Bacillus stearothermophilus. Complete amino acid sequence of a manganese enzyme. Biochemistry 19, 2873-2882 (1980)

3. Chervenka, C. H.: Long-column meniscus depletion sedimentation equilibrium technique for the analytical ultracentrifuge. Anal. Biochem. 34, 24-29 (1970)

4. Davis, B. J.: Disc-electrophoresis II. Method and application to human serum proteins. Ann. N. Y. Acad. Sci. 121, 404-427 (1964)

5. Dubois, M., K. A. Gilles, J. K. Hamilton, P. A. Revers \& F. Smith: Colorimetric method for determination of sugars and related substances. Anal. Chem. 28, 350-356 (1956)

6. EDELHOCH, H.: Spectrophotometric determination of tryptophan and tyrosine in proteins. Biochemistry 6, 1948-1954 (1967)

7. Ellman, G. L.: Tissue sulfhydryl groups. Arch. Biochem. Biophys. 82, 70-77 (1959)

8. Fairbanks, G., T. L. Steck \& D. F. H. W ALLACH: Electrophoretic analysis of the major polypeptides of the human erythrocyte membrane. Biochemistry 10, 2606-2617 (1971)

9. Fridovich, I.: Superoxide dismutases. Adv. Enzymol 35-97 (1974)

10. Fridovich, I.: Oxygen is toxic! Bio. Sci. 27, 462-466 (1977)

11. Fridovich, I.: Superoxide radicals, superoxide dismutases and the aerobic lifestyle. Photochem. Photobiol. 28, 733-741 (1978)

12. Goscin, S. A. \& I. Fridovich: The purification and properties of superoxide dismutase from Saccharomyces cerevisiae. Biochim. Biophys. Acta. 289, 276-283 (1972)

13. Harboe, N. \& A. INGILd: Immunization, isolation of immunoglobulins, estimation of antibody titre. In: A Manual of Quantitative Immunoelectrophoresis, N. H. Axelsen, S. Krell and B. Weeke, eds., Universitetsforlaget, Oslo, pp. 161-164 (1973)

14. Harris, J. I. \& H. M. Steinman: Amino acid sequence homologies among superoxide dismutases. In: Superoxide and Superoxide Dismutases, A. M. Michelson, J. M. McCord and I. Fridovich, eds., Academic Press, London, pp. 225-230 (1977)

15. Hill, H. A. O.: The superoxide ion and the toxicity of molecular oxygen. In: New Trends in Bio-Inorganic Chemistry, R. J. P. Williams and J. J. R. F. DaSilva, eds., Academic Press, London, pp. 173-208 (1978)

16. Johansen, J. T., C. O. Petersen, B. Martin, V. Haseman \& I. Svendsen: The complete amino acid sequence at copper-zinc superoxide dismutase from Saccharomyces cerevisiae. Carlsberg Res. Commun. 44, 201-217 (1979)

17. Kasper, C. B.: Fragmentation of proteins for sequence studies and separation of peptide mixtures. In: Molecular Biology, Biochemistry and Biophysic 8, Protein Sequence Determination, 2nd edition. S. B. Needleman, ed., Springer-Verlag, Berlin, pp. 114-161 (1975)

18. KeEle, B. B. Jr., J. M. MCCord \& I. Fridovich: Superoxide dismutase from Escherichia coli B: A new manganese containing enzyme. J. Biol. Chem. 245, 6176-6181 (1970)

19. KRøLL, J.: Tandem-crossed immunoelectrophoresis. In: A Manual of Quantitative Immuno- 
electrophoresis, N. H. Axelsen, J. Krøll and B. Weeke, eds., Universitetsforlaget, Oslo, pp. 5759 (1973)

20. Lowry, O. H., N. J. Rosebrough, A. L. Farr \& R. J. Randall: Protein measurement with the Folin phenol reagent. J. Biol. Chem. 193, 265275 (1951)

21. MarkLund, S. \& G. MarkLUND: Involvement of the superoxide anion radical in the autoxidation of pyrogallol and a convenient assay for superoxide dismutase. Eur. J. Biochem. 47, 469474 (1974)

22. McCord, J. M., J. A. Boyle, E. D. Day, Jr., L. J. Rizzolo \& M. L. SAliN: A manganese superoxide dismutase from human liver. In: Superoxide and Superoxide Dismutases, A. M. Michelson, J. M. McCord and I. Fridovich, eds., Academic Press, London, pp. 129-138 (1977)

23. Plummer, T. H. Jr.: A simplified method for determination of amino sugars in glycoproteins. Anal. Biochem. 73, 532-534 (1974)

24. Ravindranath, S. D. \& I. Fridovich: Isolation and characterization of a manganese-containing superoxide dismutase from yeast. J. Biol. Chem. 250, 6107-6112 (1975)

25. Sato, S. \& J. I. HaRRIS: Superoxide dismutase from Termus aquaticus. Eur. J. Biochem. 73, 373-381 (1977)

26. SCOFfone, E. \& A. Fontana: Identification of specific amino acid residues. In: Molecular Biology, Biochemistry and Biophysics, 8, Protein Sequence Determination, 2nd edition. S. B. Needleman ed., Springer-Verlag, Berlin, pp. 162-203 (1975)

27. Steinman, H. M., R. N. Vishweshwar, J. L. Abernathy \& R. L. Hill: Bovine erythrocyte superoxide dismutase. Complete amino acid sequence. J. Biol. Chem. 249, 7326-7338 (1974)

28. Steinman, H. M.: The amino acid sequence of mangano superoxide dismutase from Escherichia coli B. J. Biol. Chem. 253, 8708-8720 (1978)

29. THIERS, R. E.: Contamination in trace element analysis and its control. Meth. Biochem. Anal. 5, 273-335 (1957)

30. Villafranca, J. J., J. Yost \& I. Fridovich: Magnetic resonance studies of manganese (III) and iron (III) superoxide dismutases. J. Biol. Chem. 249, 3532-3536 (1974)

31. Weisiger, R. A. \& I. Fridovich: Superoxide dismutase: Organelle specificity. J. Biol. Chem. 248, 3582-3592 (1973) 